\title{
PENENTUAN ALAT TANGKAP UNGGULAN UNTUK IKAN PELAGIS KECIL DI PALABUHANRATU SUKABUMI
}

\author{
Determination of Best Fishing Gear for Small Pelagic Fisheries at Palabuhanratu Sukabumi \\ Oleh: \\ Joharis Silaban ${ }^{1 *}$, Mustaruddin², Deni Achmad Soeboer ${ }^{2}$ \\ ${ }^{1}$ Mahasiswa Program Studi Teknologi Perikanan Laut \\ ${ }^{2}$ Staf Pengajar Program Studi Teknologi Perikanan Laut \\ "Korespondensi: arissilaban84@gmail.com
}

\begin{abstract}
ABSTRAK
Pantai Palabuhanratu terletak pada titik koordinat $7^{0}-7^{0} 12^{\prime}$ lintang selatan dan $106^{\circ} 21^{\prime}-106^{\circ}$ 31' bujur timur. Perairan teluk ini berhadapan langsung dengan Samudera Hindia, sehingga kondisi perairan dan ikan yang terdapat di perairan teluk banyak dipengaruhi oleh perairan Samudera Hindia (PPN Palabuhanratu 2007). Permasalahan yang menyangkut keberlanjutan perikanan tangkap adalah perilaku nelayan, produktivitas penangkapan, tingkat pendapatan, ketersediaan sumberdaya ikan dan kegiatan pengelolaan (manajemen) perikanan tangkap ikan pelagis kecil itu sendiri. Untuk mengoptimalkan perikanan pelagis kecil secara berkelanjutan maka dibutuhkan analisis dengan menggunakan skoring untuk menentukan alat tangkap unggulan untuk perikanan pelagis kecil. Usaha penangkapan ikan pancing ulur memiliki nilai tertinggi berdasarkan aspek lingkungan sedangkan bagan apung adalah alat tangkap yang memiliki nilai tertinggi berdasarkan aspek teknik,sosial dan ekonomi. Secara keseluruhan alat tangkap bagan apung merupakan alat tangkap yang unggul untuk perikanan pelagis kecil. Kesimpulan dari penelitian ini adalah alat tangkap unggulan untuk perikanan pelagis kecil di perairan Pelabuhanratu berdasarkan aspek teknik, ekonomi, sosial dan lingkungan yaitu bagan apung.
\end{abstract}

Kata kunci: keberlanjutan, skoring, pengelolaan, unggulan.

\begin{abstract}
A coast of Palabuhanratu located at $7^{0}$ - $7012^{\prime}$ Latitude and 106 21' - $106^{\circ} 31^{\prime}$ Longitude. The waters directly from Indian Ocean, so that condition of water and fish more influenced by the Ocean (PPN Palabuhanratu, 2007). Some problems concerning fisheries sustainability were behavior of fisherman, fishing productivity, income level, alvailability of fish resource and the activity of small pelagic fisheries management. The purpose of this study was to determine a best fishing gear for small pelagic fisheries. The scorig method was used in data analysis to specify the best unit of small pelagic fishing. Te result showed that bagan apung (lift net) was chosen as the best fishing gear in terms of technical, economicsand environmental.
\end{abstract}

Keywords: sustainibility, scoring, management, best. 


\section{PENDAHULUAN}

Perikanan merupakan salah satu sumber utama pangan dan mata pencaharian di Palabuhanratu yang sebagian besar masih dengan skala kecil. Ketergantungan nelayan akan sumberdaya ikan mengakibatkan kecenderungan nelayan untuk melakukan perubahan strategi penangkapan ikan dalam menghadapi setiap perubahan yang berpengaruh terhadap nilai produksi hasiltangkapannya. Perikanan pelagis kecil ini sering didasarkan pada komunitas kecil di pesisir yang tergantung pada sumber daya lokal yang dapat dipengaruhi oleh kegiatan-kegiatan ekonomi disekelilingnya. Letak geografis Palabuahanratu yang berbatasan langsung dengan Samudera Hindia menyababkan aktifitas perikanan juga terus meningkat dan seiring dengan peningkatan status Pelabuhan Perikanan Palabuhanratu. Seiring dengan perkembangan waktu, penggunaan alat tangkap pancing, bagan apung apung dan payang merupakan beberapa alat tangkap yang mendominasi didaerah tersebut dan trendnya juga cenderung meningkat. Usaha perikanan dapat dipandang sebagai suatu perpaduan faktor produksi, atau sebagai suatu barang yang dihasilkan dari faktor produksi klasik seperti modal, tenaga kerja atau apapun yang termasuk dalam penyelenggaraan usaha perikanan. Perbedaanya adalah usaha perikanan sangat bergantung pada ketersediaan ikan di perairan yang tidak dapat diprediksikan secara mutlak (Kisworo 2013). Penggunaan alat tangkap ikan dalam pencapaian produksi yang baik juga harus benar-benar memperhatikan keseimbangan lingkungan dan meminimalkan dampak negatif bagi kehidupan biota perairan. Tujuan dari penelitian ini adalah menentukan alat penangkap ikan pelagis kecil unggulan dikaji dari aspek teknik, lingkungan, sosial dan ekonomi.

\section{METODE PENELITIAN}

Penelitian ini menggunakan metode kuantitatif dengan pengumpulandatadilakukan pada Bulan Oktober hingga November 2015, di Palabuhanratu, Kabupaten Sukabumi, Jawabarat. Peta penelitian disajikan pada gambar 1.

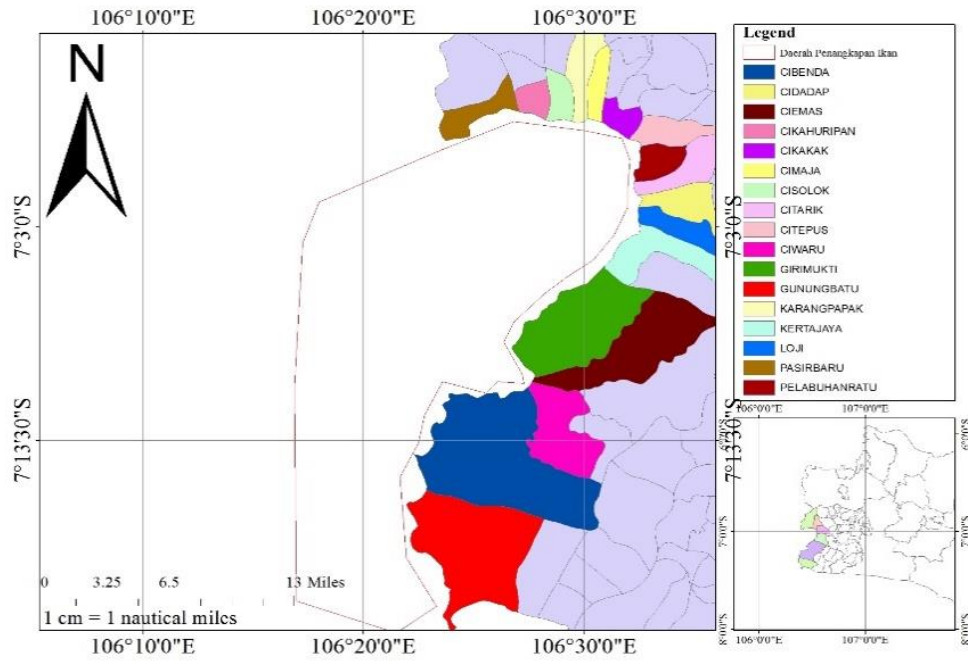

Gambar 1 Peta lokasi penelitian

Jenis dan sumber data dalam penelitian ini terdiri dari data primer dan data sekunder. Data primer mencakup data aspek tenis, ekonomi dan lingkungan dari alat tangkap ikan pelagis kecil. Data teknis tersebut mencakup: kontinuitas produksi, metode pengoperasian alat tangkap, selektifitas, penggunaan teknologi (Mustaruddin et al. 2016). Kemudian data ekonominya mencakup tingkat keuntungan yang dipereroleh dari tingkat investasi, daya beli rumah tangga nelayan, pemulihan kesehatan nelayan serta kemandirian dalam pembuatan dan perawatan unit armada penangkapan (Agustina 2016). Selanjutnya data aspek sosial yang dikaji yaitu ada tidaknya konflik antara masyarakat 
dengan nelayan, konflik antara suatu nelayan dengan nelayan lainnya, konflik nelayan dengan pemerintah, alat tangkap yang memenuhi hukum dan perundang-undangan yang berlaku. Sedangkan untuk data aspek lingkungannya mencakup, selektifitas alat tangkap, keramahan terhadap lingkungan, kualitas ikan hasil tangkapan, keamanan bagi nelayan, keamanan produk bagi konsumen, dampak pada biodiversity, keamanan bagi ikan-ikan yang dilindungi, serta bycatch rendah.

Data aspek teknik, ekonomi, sosial dan lingkungan alat tangkap dikumpulkan melalui kuesioner dan pengamatan langsung dilapangan. Responden berasal dari perwakilan nelayan yang menangkap ikan pelagis kecil di perairan Palabuhanratu. Jumlah responden sekitar 10\% (Sugiyono 2013), dari populasi nelayan tersebut dipilih secara porposive. Hal ini dimaksudkan supaya data yang diberikan lebih akurat dan lengkap karena responden mengerti betul tentang hal yang ditanyakan. Jumlah keseluruhan responden adalah sebanyak 60 orang, dimana masing-masing 20 orang dari nelayan alat tangkap pancing, nelayan bagan apung dan nelayan payang. Jumlah populasi nelayan bagan apung dan pancing adalah sekitar 200 nelayan, sedangkan jumlah responden nelayan diambil secara keseluruhan dari jumlah populasi yaitu 20 orang. Data produksi, alat tangkap dan ikan pelagis kecil yang ditangkap selama periode tertentu dikumpulkan melalui telaah pustaka terhadap laporan statistik perikanan Palabuhanratu, laporan sektor perikanan DKP Palabuhanratu dan hasil studi terkait di perguruan tinggi.

Teknik analisis skoring digunakan untuk menentukan unit penangkapan ikan pelagis kecil yang unggul berdasarkan aspek teknik, ekonomi, sosial dan lingkungan di perairan Palabuhanratu. Tujuan penentuan alat tangkap unggulan adalah untuk mendapatkan jenis alat tangkap ikan yang mempunyai performance yang baik ditinjau dari aspek teknik, ekonomi, sosial serta lingkungan sehingga merupakan alat yang cocok untuk diterapkan diperairan tersebut. Pemilihan alat tangkap yang umumnya digunakan oleh nelayan Palabuhanratu adalah alat tangkap pancing, bagan apung bagan apung dan payang. Pemilihan alat tangkap unggulan menurut Agustina (2016) dilakukan dengan menggunakan standarisasi fungsi nilai dengan rumus sebagai berikut:

$$
\begin{gathered}
V(x)=\frac{\mathrm{X}-\mathrm{Xo}}{\mathrm{X} 1-\mathrm{X} 0} \\
V(A)=\sum_{i=1}^{n} V i(X i) \quad i=1,2, \ldots n
\end{gathered}
$$

Keterangan: $V=(X)$ Fungsi nilai dari variabel $X$

$\mathrm{Xo}=$ Nilai terburuk kriteria $\mathrm{X}$

$\mathrm{X} 1=$ Nilai terbaik pada kriteria $\mathrm{X}$

$\mathrm{V}(\mathrm{A})=$ Fungsi nilai dari alternatif $\mathrm{A}$

$\mathrm{Vi}(\mathrm{Xi})=$ Fungsi nilai dari alternatif pada kriteria ke-i

$\mathrm{X} i=$ Kriteria ke-i; $\mathrm{i}=1,2,3, \ldots, \mathrm{n}$

Sifat keandalan teknologi dari unit penangkapan ikan pelagis kecil didapat dengan cara dianalisis secara deskriptif untuk meminimalisir destruktif terhadap sumber daya ikan, lingkungan sekitar, ekosistem dan masyarakat. Skor yang diberikan terhadap kriteria terkait disetiap aspek unit penangkapan ikan ini dilakukan penggunaan metode rating. Pemberian skor setiap kriteria dari setiap aspek unit penangkapan ikan pelagis kecil menggunakan kriteria-kritetia dari masing-masing aspek sebagi acuan. Kisaran skor yang diberikan adalah 1-4 dimana, skor yang diberikan semakin tinggi berbanding lurus dengan semakin tinggi pula keandalan dari aspeknya, dan sebaliknya semakin rendah skor yang diberikan maka destruktif unit penangkapan ikan tinggi.

Pada aspek ini kriteria yang dilihat adalah kontinuitas produksi, daya jangkau unit penangkapan, penggunaan teknologi dengan penilaian range 1-4 dengan nilai 1 sangat rendah (tidak ada) dan nilai 4 sangat tinggi. Selektivitas dengan penilaian range 1-4 dengan nilai 1 sangat rendah (tidak ada) dan nilai 
4 sangat selektif (tinggi). Pada kriteria aspek ekonomi, kriteria yang dilihat adalah tingkat keuntungan yang diperoleh, tingkat invetasi, kemandirian dalam pembuatan dan perawatan armada, daya beli rumahtangga nelayan, pemulihan kesehatan nelayan, peniaian range pada setiap kriteria adalah 1-4 dimana nilai 1 merupakan tidak baik (rendah) sedangkan nilai 4 sangat baik. Kriteria yang dilihat pada aspek sosial yang perlu dilihat adalah adalah ada tidaknya terjadi konflik antara masyarakat dengan nelayan, konflik dengan nelayan yang lain, konflik antara nelayan dengan pemerintah dan, memenuhi peraturan hukum dan perundang- undangan yang berlaku. Pada aspek lingkungan kriteria yang dilihat adalah selektifitas alat tangkap, keramahan terhadap lingkungan, kualitas ikan hasil tangkapan, keamanan bagi nelayan, keamanan produk bagi konsumen, dampak pada boidiversity, keamanan bagi ikan-ikan yang dilindungi, serta bycatch rendah.

\section{HASIL DAN PEMBAHASAN}

Hasil tangkapan ikan pelagis kecil pada Palabuhanratu umumnya tertangkap menggunakan alat tangkap pancing ulur, bagan apung dan payang. Menurut Subani dan Barus (1988) bagan merupakan alat tangkap yang termasuk kedalam golongan lift net (jaring angkat) yang menggunakan lampu sebagai alat bantu penangkpannya. Selanjutnya pancing ulur yang biasanya terbuat dari benang katun, nilon, polyethylene dan plastik. Selanjutnya adalah pancing ulur (hand line) termasuk dalam kelompok alat tangkap pancing, terdiri dari dua komponen utama yaitu tali (line). Mata pancing (hook) terbuat dari kawat baja, kuningan atau bahan lain yang tahan karat (Ayodhyoa 1981). Kemudian alat tangkap ikan pelagis kecil yang terakhir adalah payang. Ayodhya (1981) menyatakan bahwa alat tangkap jaring payang terdiri dari tali, kaki, badan dan kantong. Prinsip kerja dari jaring payang adalah menangkap ikan disekitar rumpon dengan menggunakan jaring yang memiliki kantong

Jenis ikan pelagis kecil yang tertangkap di Palabuhanratu sangat beragam, diantaranya adalah tembang (Sardinella fimbriata), layang (Decapterrus kurroides), lisong (Auxis rochei), teri (stolephorus $s p$.), kembung (rastrelliger spp.), selar (selaroides sp.). Perbandingan hasil tangkapan pelagis kecil antara ketiga alat tangkap pada periode 2010-2014 disajikan pada Gambar 2.

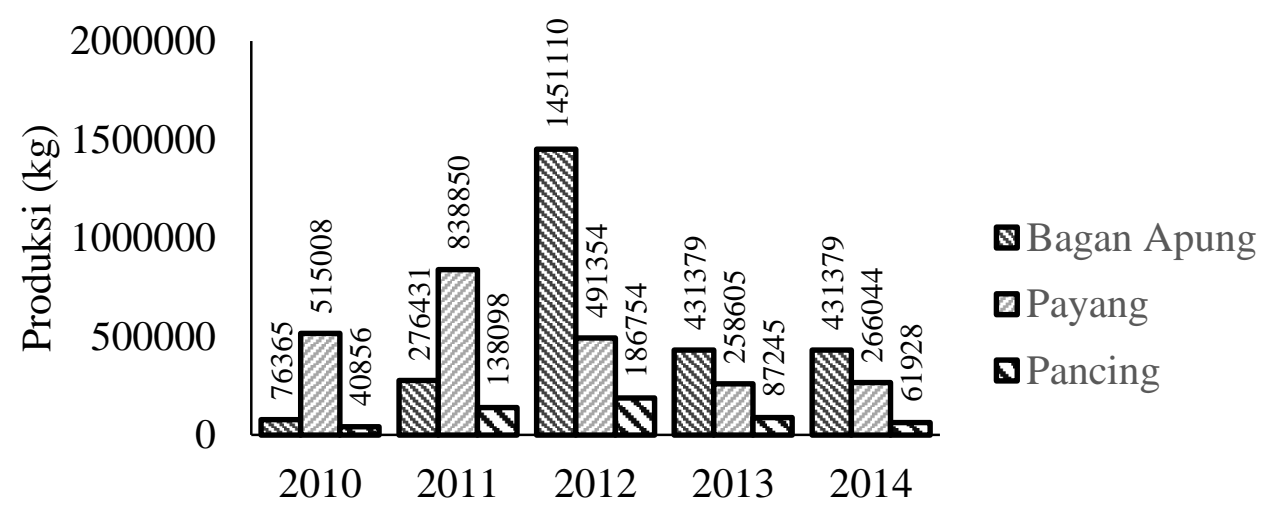

Tahun

Gambar 2 Produksi ikan di Palabuhanratu

Skoring dilakukan untuk menganalisis aspek teknis, aspek ekonomi, aspek sosial dan aspek lingkungan guna mendapatkan urutan prioritas penangkapan ikan pelagis kecil yang paling unggul dari masing-masing. 


\section{Penilaian Aspek Teknik}

Pemilihan alat tangkap yang tepat tidak terlepas dari dukungan penilaian aspek teknik dengan menggunakan pertimbangan-pertimbangan teknis yang berpengaruh seperti : (X1) kontinuitas produksi, (X2) metode pengoperasian alat tangkap, (X3) selektifitas, (X4) penggunaan teknologi. Analisis aspek teknik berkaitan erat dengan kelayakan pengoperasian alat tangkap ikan pelagis kecil.

Tabel 1 Penilaian aspek teknik

\begin{tabular}{lcccc}
\hline Usaha Penangkapan & X1 & X2 & X3 & X4 \\
\hline Pancing & 2,75 & 3 & 2,9 & 2,5 \\
Bagan apung & 3 & 2,25 & 2,7 & 2,9 \\
Payang & 2,7 & 3,6 & 2,3 & 3 \\
\hline
\end{tabular}

Keterangan : X1 = Kontinuitas produksi

$\mathrm{X} 2$ = Metode pengoperasian alat tangkap

$\mathrm{X} 3=$ Selektifitas

$\mathrm{X} 4=$ Penggunaan teknologi

Berdasarkan penilaian Aspek Teknik penggunaan teknologi pada payang memiliki nilai yang paling tinggi dari pada bagan apung dan pancing (Tabel 1). Hal ini dikarenakan alat tangkap payang ditunjang dengan kapasitas permesinan yang besar dan juga biaya konsumsi bahan bakar yang tinggi. Tinungki (2005) menyatakan bahwa biaya bahan bakar merupakan biaya operasional terbesar dari usaha perikanan, meskipun area penangkapan berada pada teluk atau selat. Area penangkapan payang juga berpindah-pindah untuk mendapatkan hasil yang maksimal tujuanya adalah mencari gerombolan ikan atau lokasi potensial untuk menangkap ikan.

Tabel 2 Standarisasi penilaian aspek teknik

\begin{tabular}{lcccccc}
\hline Alat Tangkap & V1 & V2 & V3 & V4 & AV & Prioritas \\
\hline Pancing & 0,167 & 0,556 & 1,000 & 0,000 & 1,722 & 3 \\
Bagan apung & 1,000 & 0,000 & 0,667 & 0,867 & 2,533 & 1 \\
Payang & 0,000 & 1,000 & 0,000 & 1,000 & 2,000 & 2 \\
\hline
\end{tabular}

Namun berdasarkan hasil standarisasi dari penilaian aspek teknis (Tabel 2), alat tangkap bagan apung merupakan yang paling unggul. Hal ini dikarenakan kriteria kontinuitas produksi menghasilkan nilai yang tinggi sebesar 1,000 sehingga jumlah nilai VA bagan apung $=2,533$. Selanjutnya alat tangkap payang berada pada peringkat kedua dari aspek teknik karena dari segi metode pengoperasian dan penggunaan teknologi lebih unggul dibandingkan alat tangkap ikan lainnya. Jika dibandingkan dengan alat tangkap pancing, payang lebih unggul dengan nilai adalah $(\mathrm{VA}=2,000)$ dan pada alat tangkap ikan pancing memiliki nilai $(\mathrm{VA}=1,722)$. Alat tangkap Pancing merupakan alat tangkap ikan yang memiliki teknis penangkapan dengan pengoperasiannya lebih lama dibandingkan dengan alat tangkap ikan yang lain (Hergiyatno 2013).Dari segi teknis, jumlah tenaga kerja dari masing masing alat tangkap ikan tersebut antara lain untuk pancing masing-masing 3 orang, bagan apung 1 orang dan payang 6 orang.

\section{Penilaian Aspek Ekonomi}

Pemilihan alat tangkap yang tepat tidak terlepas dari dukungan penilaian aspek teknik dengan menggunakan pertimbangan - pertimbangan ekonomi yang berpengaruh, seperti (X5) tingkat keuntungan yang diperoleh, (X6) tingkat investasi, (X7) kemandirian dalam pembuatan dan perawatan unit serta armada penangkapan, (X8) daya beli rumah tangga nelayan, (X9) pemulihan kesehatan 
nelayan. analisis aspek ekonomi ini berkaitan erat dengan kelayakan pengoperasian alat tangkap ikan pelagis kecil. Hasil penilaian aspek ekonomi dalam penentuan alat tangkap unggulan ikan pelagis kecil di Palabuhanratu disajikan pada tabel 3.

Tabel 3 Penilaian aspek ekonomi

\begin{tabular}{lccccc}
\hline Alat tangkap & X5 & X6 & X7 & X8 & X9 \\
\hline Pancing & 2,7 & 2,75 & 3,05 & 2,6 & 2,35 \\
Bagan apung & 2,55 & 3,1 & 2,9 & 2,85 & 3,05 \\
Payang & 2,5 & 3,25 & 2,85 & 2,7 & 2,4 \\
\hline
\end{tabular}

Tabel 4 Standarisasi aspek ekonomi

\begin{tabular}{lllllllc}
\hline Alat tangkap & V5 & V6 & V7 & V8 & V9 & VA & Prioritas \\
\hline Pancing & 1,000 & 0,000 & 1,000 & 0,000 & 0,000 & 2,000 & 2 \\
Bagan apung & 0,250 & 0,700 & 0,250 & 1,000 & 1,000 & 3,200 & 1 \\
Payang & 0,000 & 1,000 & 0,000 & 0,400 & 0,071 & 1,471 & 3 \\
\hline
\end{tabular}

Keterangan: V5- V9 adalah nilai standarisasi skoring

VA adalah nilai fungsi akhir pengambilan keputusan

Bagan apung merupakan unit alat tangkap paling unggul dari standarisasi aspek ekonomi dalam mendukung pengembangan sumber daya ikan pelagis kecil di perairan Palabuhanratu. Kriteria penilaiannya ditandai dengan nilai daya beli rumah tangga nelayan, pemulihan kesehatan nelayan, memiliki nilai 1,000 serta memiliki nilai investasi 0,700 sehingga nilai VA bagan apung ( $\mathrm{VA}=3,200)$. Unit alat tangkap unggul kedua dan ketiga masing-masing adalah pancing $(\mathrm{VA}=2,000)$ kemudian payang (VA=1,471). Menurut Dahuri (2003) pengembangan tingkat peran semua stakeholder terkait merupakan kunci keberhasilan ekonomi perikanan di suatu wilayah.

\section{Penilaian Aspek Sosial}

Penilaian aspek sosial juga mempengaruhi pemilihan alat tangkap yang tepat. Aspek sosial merupakan hubungan interaksi yang berhubungan langsung maupun tidak yang berpengaruh kepada komunikasi dalam masyarakat nelayan itu sendiri. Kriterianya sebagai berikut: (X10) konflik antara masyarakat dengan nelayan, (X11) konflik antara suatu nelayan dengan nelayan lainnya, (X12) konflik nelayan dengan pemerintah, (X13) alat tangkap yang memenuhi hukum dan perundang-undangan yang berlaku.

Tabel 5 Penilaian aspek sosial

\begin{tabular}{lcccc}
\hline Alat tangkap & X10 & X11 & X12 & X13 \\
\hline Pancing & 3,65 & 3,85 & 3,8 & 3,1 \\
Bagan apung & 3,95 & 3,95 & 3 & 3 \\
Payang & 3,9 & 3,9 & 2,05 & 1,65 \\
\hline
\end{tabular}

Bagan apung merupakan unit penangkapan paling unggul bidang aspek sosial dalam mendukung pengelolaan ikan pelagis kecil di Palabuhanratu. Kriteria yang menyebabkan bagan apung menjadi yang paling unggul pada aspek sosial adalah, konflik antara masyarakat dengan nelayan dan konflik nelayan dengan nelayan lainnya memiliki nilai 1,000, konflik nelayan dengan pemerintah 0,543 , alat tangkap yang memenuhi hukum dan perundang-undangan yang berlaku 0,931 dengan nilai VA yang dimiliki oleh bagan apung adalah $(\mathrm{VA}=3,474)$. Unit penangkapan ikan yang unggul urutan kedua adalah pancing dengan $(\mathrm{VA}=2,000)$ dan ketiga payang $(\mathrm{VA}=1,333)$. 
Tabel 6 Standarisasi penilaian aspek sosial

\begin{tabular}{lcccccc}
\hline Alat Tangkap & V10 & V11 & V12 & V13 & VA & Prioritas \\
\hline Pancing & 0,000 & 0,000 & 1,000 & 1,000 & 2,000 & 2 \\
Bagan apung & 1,000 & 1,000 & 0,543 & 0,931 & 3,474 & 1 \\
Payang & 0,833 & 0,500 & 0,000 & 0,000 & 1,333 & 3 \\
\hline
\end{tabular}

Keterangan: V10 - V13 adalah nilai standarisasi skoring

VA adalah nilai fungsi akhir pengambilan keputusan

Pengembangan pola perikanan pelagis yang unggulan serta berkelanjutan juga perlu memperhatikan keterbatasan faktor yang ada dalam pengelolaan perikanan. Sutisna (2007) menyatakan bahwa penentuan tingkat keberhasilan pengembangan usaha perikanan sangat ditentukan oleh aspek sosial berupa peran sumber daya manusia. Pemilihan jenis alat tagkap, penetapan operasi penangkapan ikan, pemeliharaan unit penangkapan, dan sarana prasarana perikanan, serta menjamin harmonisasi interaksi nelayan disuatu kawasan merupakan peranan besar dari kualitas sumber daya manusia.

\section{Penilaian Aspek Lingkungan}

Aspek lingkungan perikanan pelagis kecil di perairan Palabuhanratu dinilai dengan menggunakan beberapa kriteria diantaranya (X14) Selektivitas alat tangkap, (X15) Keramahan terhadap habitat ikan, (X16) Kualitas ikan hasil tangkapan, (X17) Keamanan bagi nelayan, (X18) Keamanan produk bagi konsumen, (X19) Tingkat by-catch, (X20) Dampak terhadap biodiversity, (X21) Keamanan bagi ikan yang dilindungi. Nilai yang dimasukkan pada kriteria ini adalah nilai rata-rata yang berasal dari penilaian responden.

Tabel 7 Penilaian aspek lingkungan

\begin{tabular}{lcccccccc}
\hline Alat Tangkap & $\mathrm{X}_{14}$ & $\mathrm{X}_{15}$ & $\mathrm{X}_{16}$ & $\mathrm{X}_{17}$ & $\mathrm{X}_{18}$ & $\mathrm{X}_{19}$ & $\mathrm{X}_{20}$ & $\mathrm{X}_{21}$ \\
\hline Pancing & 3,6 & 3,7 & 3,1 & 3,9 & 4 & 3,8 & 3,8 & 3,8 \\
Bagan apung & 2,5 & 3,9 & 3,7 & 4 & 3,8 & 2,9 & 4 & 3,9 \\
Payang & 3,3 & 2,25 & 3,75 & 3,85 & 3,95 & 3,85 & 3,1 & 3,8 \\
\hline
\end{tabular}

Tabel 8 Standarisasi aspek lingkungan

\begin{tabular}{lcccccccccc}
\hline Alat Tangkap & V14 & V15 & V16 & V17 & V18 & V19 & V20 & V21 & VA & Prioritas \\
\hline Pancing & 1,000 & 0,879 & 0,000 & 0,333 & 1,000 & 0,947 & 0,778 & 0,000 & 4,937 & 1 \\
Bagan apung & 0,000 & 1,000 & 0,923 & 1,000 & 0,000 & 0,000 & 1,000 & 1,000 & 4,923 & 2 \\
Payang & 0,727 & 0,000 & 1,000 & 0.000 & 0.750 & 1.000 & 0.000 & 0.000 & 3.477 & 3 \\
\hline
\end{tabular}

Keterangan : V14 - V14 adalah nilai standarisasi skoring

VA adalah nilai fungsi akhir pengambilan keputusan

Berdasarkan analisis skoring Aspek lingkungan (Tabel 7 dan Tabel 8) Alat tangkap yang paling unggul untuk Aspek lingkungan adalah pancing. Alat tangkap ini memiliki selektivitas tinggi, keamanan produk bagi konsumen dengan nilai tertinggi sebesar 1,000 dan nilai VA pancing sendiri adalah (4,937). Sesuai dengan Mustaruddin et al. (2016) dan Ayodhyoa (1981) yang menyatakan bahwa pancing merupakan alat tangkap yang selektif karena dioperasikan dengan sistem pengait menggunakan umpan tertentu dengan target yang bisa ditangkap. Berikutnya adalah bagan apung karena memiliki keramahan terhadap habitat ikan, keamanan bagi nelayan, dampak terhadap biodiversity dan keamanan bagi ikan yang dilindungi menghasilkan nilai 1,000 sehingga nilai VA bagan apung adalah 3,923. Alat tangkap unggul ketiga adalah payang dengan nilai VA 3,477. Teknologi 
penangkapan ikan ramah lingkungan adalah sebuah alat tangkap yang tidak merusak dan tidak memberi dampak negatif terhadap lingkungan.

Usaha perikanan skala kecil yang memiliki tingkat keramahan lingkungan dan selektivitas yang tinggi, nilai investasi yang rendah dan terjangkau oleh nelayan sangat diminati. Walau demikian saat ini kerusakan yang terjadi secara alamiah sangat minim jika dibandingkan dengan kerusakan yang diakibatkan oleh aktivitas manusia yang jauh lebih besar (Pet-soede 2001).

\section{Gabungan Aspek Teknik, Ekonomi, Sosial dan Lingkungan}

Hasil pemilihan unit alat tangkap ikan yang dikembangkan untuk penentuan alat tangkap unggulan ikan pelagis kecil di Palabuhanratu diperoleh dari hasil penilaian gabungan. Alat tangkap diharapkan memberikan jaminan kesinambungan kelangsungan pemanfaatan potensi sumber daya ikan pelagis kecil hingga masa mendatang sebagai bagian dari ekosistem periran di Indonesia secara khusus di perairan Palabuhanratu. Potensi sumber daya ikan di perairan dan alat tangkap sudah merupakan bagian rutinitas dari kehidupan nelayan dan masyarakat Palabuhanratu. Unit alat tangkap terhandal dan terunggul dari aspek teknik, ekonomi, sosial dan lingkungan juga akan diterapkan pada nelayan perikanan pelagis kecil.

Tabel 9 Gabungan aspek teknik, ekonomi, sosial dan lingkungan

\begin{tabular}{lcccc}
\hline Alat tangkap & $(\mathrm{V})$ & $(\mathrm{V})$ & $(\mathrm{V})$ & $(\mathrm{V})$ \\
& Aspek & $\begin{array}{c}\text { Aspek } \\
\text { Ekonomi }\end{array}$ & $\begin{array}{c}\text { Aspek } \\
\text { Sosial }\end{array}$ & $\begin{array}{c}\text { Aspek } \\
\text { Lingkungan }\end{array}$ \\
\hline Teknis & 1,722 & 2,000 & 2,000 & 4,937 \\
Pancing & 2,533 & 3,200 & 3,474 & 4,923 \\
Bagan apung & 2,000 & 1,471 & 1,333 & 3,477 \\
\hline
\end{tabular}

Keterangan: (V) Teknis, Ekonomi, Sosial dan Lingkungan adalah nilai fungsi akhir

Tabel 10 Standarisasi hasil penilaian gabungan aspek teknik, ekonomi, sosial, lingkungan

\begin{tabular}{lcccccc}
\hline \multirow{4}{*}{ Alat tangkap } & $\begin{array}{c}(\mathrm{V}) \\
\text { Aspek } \\
\text { Teknis }\end{array}$ & $\begin{array}{c}(\mathrm{V}) \\
\text { Aspek } \\
\text { Ekonomi }\end{array}$ & $\begin{array}{c}(\mathrm{V}) \\
\text { Aspek } \\
\text { Sosial }\end{array}$ & $\begin{array}{c}(\mathrm{V}) \\
\text { Aspek } \\
\text { Lingkungan }\end{array}$ & VA gab & Prioritas \\
\hline Pancing & 0,000 & 0,306 & 0,311 & 1,000 & 1,617 & 3 \\
Bagan apung & 1,000 & 1,000 & 1,000 & 0,990 & 3,990 & 1 \\
Payang & 0,342 & 0,000 & 0,311 & 1,000 & 1,654 & 2 \\
\hline
\end{tabular}

Keterangan : (VA gab) adalah total standarisasi nilai fungsi akhir pengambilan keputusan

Berdasarkan Tabel 10 unit penangkapan bagan apung merupakan alat tangkap yang paling unggul dari gabungan penilaian seluruh aspek yang terdiri dari aspek tenik, ekonomi, sosial dan lingkungan untuk dikembangkan di perairan Palabuhanratu. Hasil ini ditunjukkan dengan fungsi nilai gabungan $(\mathrm{VA}=3,990)$. Bagan apung adalah salah satu alat tangkap yang umum dan banyak digunakan oleh nelayan penangkap ikan pelagis kecil di perairan Palabuhanratu. Alat tangkap unggulan ke dua adalah payang dengan $(\mathrm{VA}=1,654)$, alat penangkapan ikan ini menjadi alternatif pilihan dalam menangkap ikan pelagis kecil. Alat tangkap pancing, menjadi pilihan alternatif ketiga setelah bagan dan payang dengan nilai gabungan $(\mathrm{VA}=1,617)$.

Produksi ikan yang stabil dengan nilai yang cukup tinggi dapat menjamin keberlanjutan ekonomi perikanan bagi daerah sekitarnya (Mamuaya et al. 2007). Ekonomi perikanan akan berkembang dengan baik sangat bergantung pada kontribusi masyarakat kawasan untuk menghasilkan produk yang dibutuhkan pasar secara berkelanjutan. Pengembangan teknologi penangkapan ikan juga 
perlu ditingkatkan karena efektifitas unit penangkapan yang dominan masih memerlukan adanya pengembangan teknologi agar produksi ikan menjadi stabil. Septifitri (2010) menyatakan bahwa tidak adanya peran serta pengembangan teknologi penangkapan dikhawatirkan akan mengakibatkan terjadinya degradasi sumber daya ikan yang signifikan. Alat tangkap bagan perlu dimodifikasi ukuran mata jaringnya agar agar alat tersebut lebih ramah lingkungan.

\section{KESIMPULAN DAN SARAN}

\section{Kesimpulan}

Alat tangkap yang terpilih sebagai unggulan untuk menangkap ikan ikan pelagis kecil di perairan Palabuhanratu adalah bagan apung (VA gab $=3,990$ ). Bagan apung unggul pada tiga dari empat aspek yang dinilai, yaitu aspek teknik ekonomi, sosial dan lingkungan.

\section{Saran}

Perlu adanya sosialisasi dari pihak terkait tentang alat tangkap prioritas unggulan yang dapat diterapkan. Bila ingin beralih pada alat tangkap unggulan sebaiknya dilakukan secara bertahap sampai dengan alat tangkap sebelumnya tidak layak operasi dan jika alat tangkap prioritas unggulan pertama tidak memungkinkan digunakan maka, alat tangkap prioritas sesudahnya sebagai alternatif pilihan yang direkomendasikan.

\section{DAFTAR PUSTAKA}

Akmaluddin, Najamuddin, Musbir. 2015. Fishing gear performance on skipjack tuna in Bone bay districk Luwu. Octopus. 4(2):309-404.

Agustina. 2016. Pola Pengembangan Usaha Ikan Karang di Kota Sabang Provinsi Aceh. Bogor (ID): Institut Pertanian Bogor. $49 \mathrm{hlm}$.

Ayodhyoa AU. 1981. Metode Penangkapan Ikan. Bogor (ID): Yayasan Dewi Sri. 91 hlm.

Dahuri R. 2003. Paradigma Baru Pembangunan Indonesia Berbasis Kelautan. Orasi Ilmiah Guru Besar Tetap Bidang Pengelolaan Sumber daya Pesisir dan Kelautan. Bogor (ID): Institut Pertanian Bogor. $233 \mathrm{hlm}$.

Prihandoko, Jahi A, Gani DS, Purnaba IGP, Amdrianto L, Tjitradjaja I. 2012. Faktor-faktor yang mempengaruhi perilaku nelayan artisanal dalam pemanfaatan sumber daya perikanan di pantai utara Jawa Barat. Jurnal Penyuluh. 9(2):158-173.

Haryono TJS. 2005. Strategi kelangsungan hidup nelayan: Studi tentang diversifikasi pekerjaan keluarga nelayan sebagai salah satu strategi dalam mempertahankan kelangsungan hidup. Jurnal Berkala Ilmiah Kependudukan. (7):119-128.

Hergiyatno IT. 2013. Perikanan pancing ulur di Palabuhanratu kinerja teknis alat tangkap. Jurnal Pusat Penelitian Pengelolaan Perikanan dan Konservasi Sumber daya Ikan Balitbang KP II. 19(3):121130.

Kisworo R. 2013. Analisis hasil tangkapan, produktivitas dan kelayakan usaha perikanan rawai dasar di PPP Bajomulyo I Kabupaten Pati. Management of Aquatic Resources Journal. 2(3):190-196.

Pet-Soede C, van Densen WLT, Pet JS, Machiels MAM. 2001. Impact of Indoensian coral reef fisheries on fish community structure and the resultant catch composition. Fisheries Research. 51:35-51. 
Septifitri. 2010. Peluang pengembangan perikanan tangkap di Provinsi Sumatra Selatan. JURNAL SAINTEK PERIKANAN. 6(1):8-21.

Subani W, Barus HR. 1988. Alat Penangkapan Ikan dan Udang Laut di Indonesia Jumal Penelitian Perikanan Laut Nomor 50 Tahun 1988/1989. Jakarta (ID): Balai Penelitian Perikanan Badan Penelitian dan Pengembangan Pertanian Departemen Pertanian. 248 hlm.

Sugiyono. 2013. Metode Penelitian Kuantitatif, Kualitatif Dan Kombinasi (Mixed Methods). Bandung (ID). CV Penerbit Alfabeta. 628 hlm.

Sutisna DH. 2007. Model pengembangan perikanan tangkap di Pantai Selatan Jawa Barat [disertasi]. Bogor (ID): Institut Pertanian Bogor. $147 \mathrm{hlm}$.

Memuaya GE, Haluan J, Wisodo SH, Astika IW. 2007. Status kota berkelanjutan perikanan tangkap di daerah kota pantai : penelaahan kasus di Kota Manado. Buletin PSP. 16(1):146-160.

Mustaruddin, Baskoro MS, Kandi O, Nasruddin. 2017. Environmental and technical aproach in the selection of fishing gear featured in WPP 571 Aceh. IJSBAR. 31(3):44-53.

Tinungki GM. 2005. Evaluasi model produksi surplus dalam menduga hasil tangkapan maksimum lestari untuk menunjang kebijakan pengelolaan perikanan lemuru di Selat Bali (disertasi). Bogor (ID): Institut Pertanian Bogor. $196 \mathrm{hlm}$. 